УДК 378.016:657:004.77

https://doi.org/10.29038/2411-4014-2020-01-216-224

Кулинич Мирослава

кандидат економічних наук, доцент, Східноєвропейський національний університет імені Лесі Українки, кафедра обліку і аудиту

м. Луцьк ORCID ID 0000-0001-9024-2924 e-mail:kulmiros@gmail.com

Шворак Анатолій, доктор економічних наук, доцент, Східноєвропейський національний університет імені Лесі Українки, завідувач кафедри обліку і аудиту, м. Луцьк; ORCID ID 0000-0003-2077-5308 _e-mail:ams95@ukr.net

Жиленко Людмила, судовий експерт ВТГЕБЗД та ОД,

Волинський науково-дослідний експертно-криміналістичний центр МВС України; м. Луцьк; e-mail: Lshylenko724@gmail.com

\title{
ВПРОВАДЖЕННЯ ЦИФРОВОЇ ГРАМОТНОСТІ В УМОВАХ МАЙБУТНІХ ЗМІН ПРОФЕСІЇ БУХГАЛТЕРА
}

У статті досліджуються сучасні тенденції змін професії бухгалтера. Консервативний контекст професії бухгалтера змінюється нестандартним мисленням фахівця, який будучи менеджером-управлінцем, аналітиком приймає рішення, обгрунтовані законодавчими вимогами, які мінімізують ризики операційної діяльності, демонструє лідерські та комунікативні навички, вміння швидко оцінювати ситуацію і прораховувати можливі ризики, що особливо важливо в бізнесі. Цифрові трансформації у економіці впливають на професію бухгалтера, зокрема на формування його фахових компетенцій і цифрову грамотність. В умовах цифрових перетворень у економіці різноманітний світ IT-рішень пропонує бухгалтеру безліч інструментів, 3 яких він повинен вибрати ту комбінацію, яка максимально відображає завдання з організації бухгалтерського обліку на підприємстві.

Ключові слова. Цифрова грамотність, професія бухгалтера, фахові компетенції, автоматизація, програмне забезпечення, менеджмент.

Кулинич Мирослава, кандидат экономических наук, доцент, Восточноевропейский национальный университет имени Леси Украинки, кафедра учета и аудита, г. Луцк

Шворак Анатолий, доктор экономических наук, доцент, Восточноевропейский национальный университет имени Леси Украинки кафедра учета и аудита, г. Луцк

Жиленко Людмила, судебный эксперт ОТГЕСЗИ и ОД, Волынский научно-исследовательский экспертно-криминалистический центр МВД Украины; 


\title{
ВНЕДРЕНИЕ ЦИФРОВОЙ ГРАМОТНОСТИ В УСЛОВИЯХ БУДУЩИХ ИЗМЕНЕНИЙ ПРОФЕССИИ БУХГАЛТЕРА
}

В статье исследуются современные тенденции изменений профессии бухгалтера. Консервативный контекст профессии бухгалтера меняется нестандартным мышлением специалиста, который будучи менеджером управленцем, аналитиком принимает решения, обоснованные законодательными требованиями, которые минимизируют риски операционной деятельности, демонстрирует лидерские и коммуникативные навыки, умение быстро оценивать ситуацию и просчитывать возможные риски, что особенно важно в бизнесе. Цифровые трансформации в экономике влияют на профессию бухгалтера, в частности на формирование его профессиональных компетенций и цифровую грамотность. В условиях цифровых преобразований в экономике разнообразный мир IT-решений предлагает бухгалтеру множество инструментов, из которых он должен выбрать ту комбинацию, которая максимально отражает задачи по организации бухгалтерского учета на предприятии.

Ключевые слова. Цифровая грамотность, профессия бухгалтера, профессиональные компетенции, автоматизация, программное обеспечение, менеджмент.

\author{
Kulynych Myroslava, \\ PhD in Economics, Associate Professor, \\ Lesya Ukrainka Eastern Europen National University, \\ Department of Accounting and Auditing \\ Lutsk \\ Shvorak Anatolii, \\ Doctor of Economics, Assosiate Professor, \\ Lesya Ukrainka Eastern Europen National University, \\ Department of Accounting and Auditing \\ Lutsk \\ Zhilenko Lyudmila, \\ judicial expert of Volyn Research Experimental Forensic \\ Center of the Ministry of Internal Affairs of Ukraine; \\ Lutsk
}

\section{IMPLEMENTATION OF DIGITAL LITERACY UNDER CONDITIONS OF THE FUTURE CHANGES IN ACCOUNTANT PROFESSION}

Introduction. The article examines the current trends in the accountant profession. The conservative context of the accountant profession is changed by the non-standard thinking of a specialist, who being a manager-administrator and analyst makes decisions justified by legal requirements, minimizes risks of operating activity as well as demonstrates leadership and communication skills, ability to quickly evaluate the situation. It has gained key importance in business.

The purpose of the article is to study the introduction of digital literacy, digital culture in the conditions of the modern accountant professional competencies formation and future changes of this profession.

Results. Digital transformations in the economy affect the accountant profession including both the formation of his professional competencies and digital literacy. In the context of digital transformations in the economy, the diverse world of IT solutions offers the accountant many tools from which he must choose the combination that reflects the task on organization of accounting at the enterprise.

The modern accountant adopts a variety of programs for accounting and tax registration, freely guides in their advantages and selects the best decision for the enterprise. It designs business processes and sets the task for the developers in accordance with the enterprise accounting policies. He manages the new technology.

In practice, the important role of keeping the accountant's professional priorities is that he deals with the limited staff and has to:

- independently select software and hardware for automation of accounting system;

- set up accounting software;

- independently search for ways to master the latest software products. 
And this requires having the appropriate level of competences acquired in the educational institutions training and the development and improvement of organizational nature competencies needed in the conditions of a particular business entity.

Conclusions. Thus, in the future a professional accountant is viewed as a driver of changes in skills that potentially affect competences and personal qualities. In doing so, the professional digital accountants will be asked for decades to come in order to help the educators, employers, and professional organizations to articulate the transformation of the accountant profession.

Key words: digital literacy, accountant profession, professional competences, automation, software, management.

Розвиток будь-якої компанії передбачає синергію сумлінного ставлення до обов'язків і захопленості професією, у тому числі й у сфері бухгалтерії. Успішність діяльності більш ніж наполовину залежить від налагодженого бухгалтерського обліку.

Бухгалтер веде бухгалтерський облік операцій підприємства або установи, займається оптимізацією оподаткування, несе відповідальність за формування облікової політики. У коло його обов'язків входить як первинна обробка документів обліку, так і завдання, які вимагають досвіду і спеціального рівня кваліфікації, зокрема оформлення податкових документів, формування квартальної та річної звітності, комунікації з податковою інспекцією та іншими контролюючими органами.

Сучасний бухгалтер - це i менеджер-управлінець, i аналітик, i досвідчений різнобічний фахівець, що приймає рішення, обгрунтовані законодавчими вимогами, які мінімізують ризики операційної діяльності, демонструє лідерські та комунікативні навички, вміння швидко оцінювати ситуацію і прораховувати можливі ризики, що особливо важливо в бізнесі.

Прийнято вважати, що професія бухгалтера - це консерватизм. Але для сучасного бухгалтера таке визначення давно не актуальне. У сучасному світі цінується нестандартне мислення - саме воно дозволяє приймати рішення на поєднанні сухих цифр і різноманітності зовнішніх факторів.

Цілком можна припустити, що через десять років бухгалтером будуть називати лише висококваліфікованого фахівця, консультанта щодо обліку, чия робота буде полягати в розробці і коригування правил для програми, складанні вказівок, як обробляти вхідні дані, щоб підсумок відповідав вимогам як внутрішніх, так і зовнішніх регламентів і стандартів. Але сьогодні, професія бухгалтера в першу чергу вимагає підготовки з дисципліни "Бухгалтерський облік" та ряду обліковоаналітичних дисциплін і передбачає ведення обліку за обліковими функціями на підприємстві та складання податкової і фінансової звітності.

В умовах цифрових перетворень у економіці різноманітний світ IT-рішень пропонує бухгалтеру безліч інструментів, 3 яких він повинен вибрати ту комбінацію, яка максимально відображає завдання з організації бухгалтерського обліку на підприємстві. Тому, для того щоб добитися успіху в цифрову еру, кампаніям необхідно вибудувати свою цифрову культуру - унікальну впевненість у своїх цифрових силах, загальні цінності, переконання, методи і припущення, які визначають поведінку компаній.

Аналіз досліджень і публікацій. Науковий доробок 3 дослідження впливу цифрових трансформацій у економіці на професію бухгалтера, зокрема на формування його фахових компетенцій і цифрової грамотності досить значний і свідчить про те, що ця проблематика перебуває постійно у полі зору науковців. Як зазначає Козловський Ю. М. і Яремко І. Й. однією 3 найважливіших проблем професійної освіти фахівців є формування у них навичок, цінностей, мотивації до особистої участі у вирішенні професійних проблем для покращення якості майбутньої діяльності. Особлива роль в цьому процесі належить формуванню професійної компетентності в контексті сучасного феномену економіки, і зокрема це стосується безпосередньо фахівців з обліку та оподаткування [1].

Досліджуючи дане питання Матюха М. М. вважає, що однією 3 глобальних цілей інформатизації утворення умінь є професійне навчання фахівців, що володіють високою комп'ютерною компетентністю, які вміють втілювати і поєднувати нові інформаційні технології в процесі навчання та у своїй професійній діяльності [2]. 
У вивченні проблеми освітньої підготовки та практичної діяльності бухгалтерів І. Е. Ахмед наголошує на важливості підготовки таких випускників, які б могли легко адаптувати свої професійні навики до мінливого середовища високих технологій, оскільки розширення світового ринку у поєднанні зі старінням наявної робочої сили створюють прецедент постійного пошуку компетентних бухгалтерів [3].

Формування професійної компетенції майбутнього фахівця з обліку і оподаткування Кулинич М. Б. і Шворак А. М. вбачають у впровадженні в навчальний процес новітніх комп'ютерних технологій, що дасть можливість підвищити ефективність надання освітніх послуг під час викладання дисциплін обліково-аналітичного циклу та в подальшому застосувати набуті знання на практиці відповідно до сучасних умов господарювання $[4,5]$.

Шевченко С. В. аргументує актуальність визначення параметрів готовності майбутнього бухгалтера до автоматизації обліку, показує доцільність використання компетентнісного підходу в умовах цієї готовності, наводить перелік фахових компетенцій майбутнього бухгалтера [6].

При компетентністно - орієнтованому підході наголос робиться на компетенції, які становлять певну сферу, коло діяльності, наперед визначену систему питань щодо яких особистість повинна бути добре обізнана, тобто володіти певним набором знань, умінь, навичок та власного до них ставлення. 3 огляду на це Гаврілова Л. Г., Топольник Я В. обгрунтовує цифрову грамотність, як складову цифрової компетентності вказує передусім на досконале користування електронними засобами, на сформованість умінь і навичок роботи 3 «цифрою» [7], що набуває особливої актуальності в умовах трансформації професії бухгалтера.

Досліджуючи запити роботодавців на предмет задоволеності ними якістю бухгалтерської освіти випускників вищих навчальних закладів Аверина О.І., Колесник Н. Ф., Свешникова О. Н. зазначають, що найбільш запитуваними для практичної роботи є бухгалтери, що володіють як професійними навичками та вміннями, так і організаційними та управлінськими здібностями i знаннями інформаційних технологій, а також іноземних мов [8].

Плікус І., Жукова Т., Осадча О., моделюючи професію бухгалтера в епоху цифрових трансформацій на основі ключових напрямів компетентностей, виокремлює цифовий фактор [9].

Оцінюючи наукові здобутки дослідників з даного питання слід зазначити, що рівень цифрової грамотності має значний вплив на формування професійних якостей фахівців з бухгалтерського обліку. Ця проблематика $є$ актуальною в умовах сучасних цифрових перетворень і потребує подальших досліджень.

Метою даної статті є дослідження впровадження цифрової грамотності, цифрової культури в умовах формування фахових компетенцій сучасного бухгалтера і майбутніх змін даної професії.

Виклад основного матеріалу. Цифрова грамотність $є$ загальною у використанні дефініцією зарубіжної педагогіки, яка вказує передусім на досконале користування електронними засобами, на сформованість умінь і навичок роботи 3 «цифрою». Утім, деякі дослідники вкладають у іiі тлумачення характеристики, що наближають це поняття до ІТ-компетентності. Гаврілова Л. Т. і Топольник Я. В. вважають що цифрова компетентність найчастіше визначається на основі загальноприйнятого розуміння компетентності як інтегрованої здатності особистості, яка складається із знань, умінь, досвіду, цінностей і ставлення, що можуть цілісно реалізовуватися на практиці. Це поняття $\epsilon$ узагальнюючим для попередніх, оскільки сформована цифрова компетентність вміщує і цифрову грамотність, і цифрову культуру [7]. Компетентність - якість особистості, їі певне надбання, що грунтується на знаннях, досвіді, моральних засадах і проявляється в критичний момент за рахунок вміння знаходити зв'язок між ситуацією та знаннями, у прийнятті адекватних рішень нагальної проблеми.

Таким чином, бухгалтерія в сучасному світі вже давно стала не просто вмінням правильно працювати з цифрами. Тепер це - переплетення знань з різних сфер діяльності (в тому числі, юриспруденції та інформаційних технологій), які досвідчений і далекоглядний бухгалтер прагне засвоїти якомога швидше.

Сучасний бухгалтер має не тільки фундаментальні знання в обліку, а й емоційний інтелект і нестандартне цифрове мислення [12]. Підготовка фахівців 3 обліку та аналізу, їх професійне становлення і професійна компетентність $є$ важливим аспектом педагогічної науки й освітньої практики. У практичній діяльності бухгалтер стикається в основному з інформацією (знаковими 
системами), іншими суб’єктами (контрагентами), що беруть участь в економічних відносинах. Тобто професія бухгалтера належить до типу «людина - знакова система» і «людина - людина». Отже, основними професійними компетенціями в цій сфері будуть: енциклопедичність, високий рівень інформаційної компетентності, розуміння суті економіки і фінансів, системне мислення, одночасне оперування кількома системами, здатність оперативно оцінювати загальну ситуацію (прикидання) i прогнозувати їі розвиток, толерантність, розумна педантичність тощо [1].

Формування кадрів до роботи в умовах бурхливого розвитку інформаційних технологій i пов'язаного 3 ним зламу традиційного змісту бухгалтерської праці належить до зони відповідальності системи фахової підготовки [6].

У зв’язку з тим особливої актуальності набуває системний критерій у вишколі спеціалістів. 3 позицій системного підходу Козловський Ю. М. і Яремко І. Й. розглядають формування професійної компетентності майбутніх фахівців обліку та аудиту через основну ідею: розгляд системи досліджуваного процесу з погляду всебічності, цілісності. Системний підхід забезпечує комплексне вивчення проблеми дослідження і використовується через цілісну реалізацію таких положень: формування професійної компетентності засобами самостійної роботи; дослідження системи та вивчення їі структурних компонентів, системоутворюючих чинників, функціональних зв'язків і стосунків тощо [1].

Сучасний бухгалтер приймає різноманітність програм для ведення бухгалтерського i податкового обліку, вільно орієнтується в їх перевагах і сам обирає краще рішення для свого підприємства. Він створює бізнес-процеси й ставить розробникам завдання відповідно до облікових політик підприємства. Він управляє новою технологією.

На практиці важливу роль дотримання пріоритетів професійної діяльності бухгалтера відіграє те, що у зв’язку з обмеженим штатом йому доводиться:

- самостійно добирати програмні й апаратні засоби для автоматизації роботи системи бухгалтерського обліку;

- налаштовувати бухгалтерське програмне забезпечення;

- самостійно шукати шляхи опанування новітніми програмними продуктами.

А це потребує наявності належного рівня компетенцій, здобутих при підготовці в учбових закладах, розвитку i вдосконалення компетенцій організаційного характеру, необхідних в умовах конкретного господарюючого суб'єкта. Об'єктивна реальність диктує основні вимоги до бухгалтера, не пов'язані зі знанням бухгалтерського обліку: відповідальність, організованість, математичні здібності, висока концентрація уваги і пам'яті, логічне мислення, висока здатність до самостійного навчання. Також важливо, щоб компанія і співробітник відчували взаємну довіру. Однак усього цього мало. Найважливішою умовою функціонування професії обліковця в цифровому суспільстві є те, що сучасний бухгалтер повинен постійно вчитися.

Світ бухгалтера можна розділити на дві зони розвитку знань:

- знання поточного законодавства, відстеження змін і впровадження правильних законодавчо підтверджених методів обліку на підприємстві;

- технологічне вдосконалення. Зміст праці бухгалтера змінюється під впливом розвитку цифрових технологій передачі даних.

3 усіма органами контролю, банками та контрагентами бухгалтер вже спілкується за допомогою сучасних інформаційних технологій. Різноманітний світ IT-рішень пропонує бухгалтеру безліч інструментів, 3 яких він повинен вибрати ту комбінацію, яка максимально відображає завдання 3 організації бухгалтерського обліку на підприємстві.

Бурхливий розвиток І-технологій сприяє становленню нового формату професійної діяльності бухгалтерів, що виражається в поширенні “аутсорсингу”, сутність якого полягає в бухгалтерському обслуговуванні підприємства нештатним фахівцем (або групою фахівців). Характерними ознаками такого формату роботи є віддаленість робочого місця від офісу та одночасне обслуговування бухгалтером декількох підприємств [6]. У зв’язку з цим підготовка бухгалтерів до роботи в умовах зламу традиційного змісту бухгалтерської праці належить до зони відповідальності системи фахової підготовки. Бухгалтер стає носієм цифрової культури на підприємстві, його професійні навики будуть піддаватися постійній трансформації в залежності від мінливого цифрового середовища. 
Всі ці особливості, як зазначає Герасимова Є. Б., повинен враховувати менеджмент компанії, плануючи взаємодію з клієнтами, ресурсозабезпеченість, стратегію поведінки на ринку. Підбір персоналу і управління людськими ресурсами - представниками цифрової культури - потребує особливих психологічних і соціальних навичок, нової постановки завдань і організації роботи [11].

Можна припустити, що через десять років бухгалтером будуть називати лише висококваліфікованого фахівця, консультанта щодо обліку, чия робота буде полягати в розробці і коригування правил для програми, складанні вказівок, як обробляти вхідні дані, щоб підсумок відповідав вимогам як внутрішніх, так і зовнішніх регламентів і стандартів.

Міжнародна Асоціація дипломованих сертифікованих бухгалтерів (англ. ACCA - Association of Chartered Certified Accountants) у червні 2016 року опублікувала результати своїх досліджень за 2014-2015 pp. - «Drivers of change and future skills», протягом яких були зібрані думки понад 2000 професійних бухгалтерів. Найбільш одностайно учасники дослідження висловили впевненість у тому, що в найближчі десять років на професію бухгалтера вплинуть наступні зміни:

1. Гармонізація міжнародних бухгалтерських та бізнес-стандартів.

2. Освоєння бізнесом хмарних обчислень.

3. Активна участь жінок на ринку праці.

4. Аналіз даних і нові методології аналізу.

5. Розширення очікувань і вимог зацікавлених сторін щодо вимірювання цінності бізнесу (business value).

6. Ресурсні конфлікти.

7. Майбутнє цифрових технологій.

8. Посилення захисту локальних робочих місць від іноземних впливів.

9. Надання послуг аутсорсингу у публічному секторі [13].

Уже сьогодні професійні бухгалтери стали лідерами бізнес-структур, державних підприємств разом із досвідченими адвокатами і стратегічними радниками. Для зростання професійних якостей бухгалтера у майбутньому необхідним буде комбінація професійних компетенцій, що складаються 3 технічних знань (цифрових навиків), фахових навичок і здібностей та етичних (психологічних) якостей.

Досліджуючи розвиток фаху бухгалтера майбутнього Плікус I., Жукова Т., Осадча О. запропонували модель професії, що сформувалась під впливом цифрових технологій і включає у себе:

- Інтелект - здатність отримувати та використовувати знання для вирішення проблем.

- Креативність - здатність використовувати наявні знання в новій ситуації, установлення зв'язків, генерування нових ідей тощо.

- Цифровий фактор - застосування існуючих та нових цифрових технологій.

- Емоційний інтелект - здатність ідентифікувати власні емоцій та емоції інших, використовувати ïx для вирішення завдань, регулювати й управлять ними.

- Бачення - здатність точно прогнозувати майбутні тенденції шляхом екстраполяції існуючих тенденцій і фактів.

- Досвід - здатність і навички для розуміння очікувань клієнтів, створення цінності тощо.

Бухгалтер майбутнього потребує оптимального співвідношення професійних компетенцій (технічних знань, навичок та вмінь) із міжособистісною поведінкою, оскільки бухгалтери становляться лідерами, надійними експертконсультантами і стратегічними радниками для організацій у державному та приватному секторах $[9,13]$.

Майбутній професійний бухгалтер повинен регулювати бізнес на стійкому курсі між ризиком i можливістю. Це вимагає співробітництва, стратегічного мислення і реального розуміння оцінки бізнес- середовища, людей і їх можливостей.

3 впевненістю можна сказати, що епоха бухгалтерів як виконавців суто облікових процедур дійсно закінчується. Сучасні бізнес-потреби професійних бухгалтерів $є$ набагато більшими. Разом 3 фаховими, технічними, етичними, цифровими, експертними знаннями сучасний бухгалтер повинен володіти іншим набором навичок, можливо, опосередковано пов'язаних з його професією. А саме, креативність, емоційний інтелект і бачення. 
Висновки. Таким чином, професійний бухгалтер у майбутньому - це рушій зміни навиків, які потенційно впливають на компетенції та особисті якості. При цьому професійні цифрові бухгалтери будуть запитувані на наступні десятиліття, що допоможе педагогам, роботодавцям і професійним організаціям сформулювати тенденції трансформації професії бухгалтера.

Осмислення цифрової культури як показника успішної професійної діяльності фактично переводить це поняття у смислове поле цифрової грамотності. Цифрова грамотність як широковживана дефініція зарубіжної педагогіки вказує передусім на досконале користування електронними засобами, на сформованість умінь і навичок роботи 3 «цифрою», у тому числі і сучасного бухгалтера. Цифрова компетентність найчастіше визначається на основі загальноприйнятого розуміння компетентності як інтегрованої здатності особистості, яка складається із знань, умінь, досвіду, цінностей і ставлення, що можуть цілісно реалізовуватися на практиці. [7].

Сучасний бухгалтер - це i менеджер-управлінець, i аналітик, i досвідчений різнобічний фахівець, який демонструє лідерські та комунікативні навички, вміння швидко оцінювати ситуацію і прораховувати можливі ризики, що особливо важливо в бізнесі.

В сучасному цифровому суспільстві комп'ютерний бекграунд повинен мати кожен фахівець, але для бухгалтерів це просто must have, оскільки вони за родом професійної діяльності змушені працювати 3 величезною кількістю інформації. I цю інформацію потрібно вміти аналізувати, обробляти і ефективно використовувати при прийнятті рішень. Володіння цифровими технологіями $\epsilon$ необхідною умовою для успішного розвитку фінансових фахівців, а отже без їх цифрової грамотності процеси автоматичного збору і обробки стануть неможливими. Тому найважливішою умовою функціонування професії бухгалтера в цифровому суспільстві $є$ те, що сучасний бухгалтер повинен постійно вчитися, щоб відповідати вимогам сучасності.

\section{Джерела та література}

1. Козловський Ю. М., Яремко І. Й. Формування професійної компетентності майбутніх фахівців 3 обліку та аналізу. Глобальні та наиіональні проблеми економіки. Миколаӥвський наиіональний університет імені В.О. Сухомлинського Випуск 22. 2018 http://global-national.in.ua/archive/22-2018/176.pdf (дата звернення: 05.02.2020p.)

2. Матюха М. М. Інноваційні підходи до підготовки фахівців обліково-аналітичного напрямку в умовах модернізації освіти [Текст] Вісник Київського національного університету технологій та дизайну : матеріали $\mathrm{V}$ міжнар. Наук.-практ. Конф. «Ефективність організаційно-економічного механізму інноваційного розвитку вищої освіти України», 2 жовтня 2015 р. - 2015. - Спец. Вип. : Серія «Економічні науки». - С. 203-212.

3. Ahmed I. E. Bridging the gap between governmental accounting education and practice. Growing Science. 2019. Vol. 5. Issue 1. Pp. 21-30. DOI: 10.5267/j.ac.2018.6.003].

4. Кулинич М. Б, Шворак А. М. Необхідність запровадження дистанційного навчання при викладанні дисциплін обліково-аналітичного циклу / Викладання економічних дисциплін в умовах глобалізаційних та інтеграційних перетворень: міжнародна науково-методична конферениія, 1 червня 2018 . Харківського національного автомобільно-дорожнього університету

5. Кулинич М. Б. Застосування технологій дистанційного навчання під час викладання обліковоаналітичних дисциплін. Економічний часопис Східноєвропейського національного університету імені Лесі Українки : журнал. - Луцьк : Вежа-Друк, 2015. - № 3. - С. 79 - 85

6. Шевченко С. В. Параметри готовності майбутніх бухгалтерів до автоматизації бухгалтерського обліку на малих підприємствах. Педагогіка формування творчої особистості у вищій $і$ загальноосвітній иколах file:///C:/Users/Admin/Downloads/Pfto_2015 41_54\%20(1).pdf (дата звернення: 02.02.2020p.)

7. Гаврілова Л. Г., Топольник Я. В. Цифрова культура, цифрова грамотність, цифрова компетентність як сучасні освітні феномени. Інформаційні технології $i$ засоби навчання, 2017, Том 61, №5, DOI: https://doi.org/10.33407/itlt.v61i5.1744] (дата звернення: 04.02.2020p.)

8. Аверина О. И., Колесник Н. Ф., Свешникова О. Н. Подготовка бухгалтеров в системе современного отечественного высшего образования: состояние и перспективы Интегращия образования. Т. 21, № 3. 2017

DOI: $10.15507 / 1991-9468.088 .021 .201703 .546-562$ 
9. Плікус І., Жукова Т., Осадча О. Модель професії бухгалтер в епоху цифрових трансформацій: ключові напрями компетентностей бухгалтера. Приазовський економічний Вісник. 2019. Вип.1 (12). C.200-205.

10. Минковская А. А. Дигитализация бухгалтерского учета и отчетности, и возможность ее развития в Республике Беларусь. Фізико-математична освіта. 2018. Випуск 4(18). С. 112-114.

DOI 10.31110/2413-1571-2018-018-4-018

11. Герасимова Е. Б. Анализ деятельности экономического субъекта и цифровая культура. Мир новой экономики. 2019;13(2):111120. DOI: 10.26794/2220-6469-2019-13-2-111-120

12. Галелюка M. Must-have компетенції: сучасний бухгалтер та IT-технологіï. Na chasi (онлайн-видання). 23.04.2018. URL: https://nachasi.com/2018/04/23/suchasnyj-buhgalter-ta-it/ (дата звернення: 15.02.2020).).

13. Professional accountants - the future: drivers of change and future skills. The global body for professional accountants (онлайн-видання). URL:https://cutt.ly/BttZVme (дата звернення: 15.02.2020).)

14. В. О. Кудлай, Цифрова грамотність особистості в контексті розвитку інформаційного суспільства, Вісник Маріупольського державного університету. Серія: філософія, культурологія, соиіологія, вип. 10, с. 97104, 2015.

15. «Цифрова адженда України - 2020». [Електронний ресурс]. Доступно: https://cutt.ly/NttBrYT

\section{References}

1. Kozlovs`ky`j Yu. M., Yaremko I. J. (2018) Formuvannya profesijnoyi kompetentnosti majbutnix faxivciv z obliku ta analizu [Formations of professional competence of future experts from account and the analysis] Global'ni ta nacional'ni problemy`ekonomiky`. My'kolayivs ky`j nacional'ny`j universy`tet imeni V. O. Suhomly`ns'kogo.- Global and national problems of economy. Nikolaev national university of V. A. Sukhomlinsky http://globalnational.in.ua/archive/22-2018/176.pdf (data zvernennya: 05.02.2020r.) [in Ukrainian].

2. Matyuha M. M. (2015) Innovacijni pidhody` do pidgotovky` fahivciv oblikovo-anality`chnogo napryamku v umovah modernizaciyi osvity` [Innovative approaches to training of specialists registration and analytical the direction in the conditions of modernization of education] Visny`k Ky`yivs`kogo nacional`nogo universy`tetu texnologij ta dy'zajnu : materialy'V mizhnar. Nauk.-prakt. Konf. «Efekty`vnist` organizacijno-ekonomichnogo mexanizmu innovacijnogo rozvy 'tku vy 'shhoyi osvity' Ukrayiny'»- The bulletin of the Kiev national university of technologies and design: Materials V m_zhnar. Sciences. - prakt. Konf. "Efficiency of the organizational and economic mechanism of innovative development of the higher education of Ukraine", 2 zhovtnya $2015 \mathrm{r}$. - Specz. Vy 'p. : Seriya "Ekonomichni nauky'». - C. 203-212. [in Ukrainian].

3. Ahmed I. E. (2019) Bridging the gap between governmental accounting education and practice. Growing Science. 2019. Vol. 5. Issue 1. Pp. 21-30. DOI: 10.5267/j.ac.2018.6.003]. [in English].

4. Kuly`ny`ch M. B, Shvorak A. M. (2018) Neobhidnist`zaprovadzhennya dy`stancijnogo navchannya pry` vy`kladanni dy`scy`plin oblikovo-anality`chnogo cy`klu [Need of introduction of distance learning when teaching disciplines of a registration and analytical cycle] Vy`kladannya ekonomichny'x dy'scy'plin $v$ umovax globalizacijny`x ta integracijny`h peretvoren`: mizhnarodna naukovo-metody`chna konferenciya, 1 chervnya $2018 \mathrm{r}$. Harkivs`kogo nacional nogo avtomobil`no-dorozhn`ogo universy`tetu [in Ukrainian].

5. Kuly`ny`ch M. B. (2015) Zastosuvannya tehnologij dy`stancijnogo navchannya pid chas vy`kladannya oblikovo-anality`chny`h dy`scy`plin. [Of use of technologies of distance learning during teaching registration and analytical disciplines.] Ekonomichny`j chasopy`s Shidnoyevropejs`kogo nacional`nogo universy`tetu imeni Lesi Ukrayinky`Economic chasopis East European national university of Lesya Ukrainka vol 3 [in Ukrainian].

6. Shevchenko S. V. (2015) Parametry` gotovnosti majbutnih buhgalteriv do avtomaty`zaciyi buhgalters`kogo obliku na maly`h pidpry`yemstvah. [Parameters of readiness of future accountants for automation of accounting at small enterprises] Pedagogika formuvannya tvorchoyi osoby`stosti u vy`shhij i zagal’noosvitnij shkolax/ - Pedagogics of formation of the creative person at the highest and general education file schools file:///C:/Users/Admin/Downloads/Pfto_2015_41_54\%20(1).pdf (data zvernennya: 02.02.2020r.) [in Ukrainian].

7. Gavrilova L. G., Topol`ny`k Ya. V. Cy`frova kul`tura, cy`frova gramotnist', cy`frova kompetentnist` yak suchasni osvitni fenomeny`. Informacijni texnologiyi i zasoby` navchannya, 2017, Tom 61, \#5, DOI: https://doi.org/10.33407/ittt.v61i5.1744] (data zvernennya: 04.02.2020r.) [in Ukrainian].

8. Avery`na O. Y`., Kolesny`k N. F., Sveshny`kova O. N. (2017) Podgotovka buhgalterov v sy`steme sovremennogo otechestvennogo vysshego obrazovany`ya: sostoyany`e y` perspekty`vy i`ntegracy`ya obrazovany`ya. [Training of accountants in the system of modern domestic higher education: state and prospects education Integration] T. 21, \# 3 .

DOI: 10.15507/1991-9468.088.021.201703.546-562 [in Russian].

9. Plikus I., Zhukova T., Osadcha O. (2019) Model` profesiyi buhgalter v epohu cy`frovy`h transformacij: klyuchovi napryamy` kompetentnostej buhgaltera. [Model of a profession the accountant during an era of digital 
transformations: Key directions of competences of the accountant] Pry`azovs`ky`j ekonomichny`j Visny`k - Azov Economic bulletin. Vol.1 (12). [in Ukrainian].

10. My`nkovskaya A. A. Dy`gy`taly`zacy`ya buhgalterskogo ucheta y`otchetnosty`, y`vozmozhnost ee razvy`y`ya v Respubly`ke Belarus` [Digitalization of accounting and the reporting, and a possibility of its development in Republic of Belarus]. Fizy ko-matematy chna osvita. - Physical and mathematical education 4(18). S. 112-114.

DOI 10.31110/2413-1571-2018-018-4-018 [in Russian].

11. Gerasy`mova E. B. (2019) Analy`z deyatel`nosty` эkonomy`cheskogo subekta y` cy`frovaya kul ’ura. [Analysis of activity economic to the person and digital culture]. My`r novoj ekonomy 'ky`.- World of new economy. 2019;13(2):111120. DOI: 10.26794/2220-6469-2019-13-2-111-120 [in Russian].

12. Galelyuka M. (2018) Must-have kompetenciyi: suchasny`j buhgalter ta IT-texnologiyi. [Competence Musthave: Modern accountant and IT technologies] Na chasi (onlajn-vy`dannya). 23.04.2018. URL: https://nachasi.com/2018/04/23/suchasnyj-buhgalter-ta-it/ (data zvernennya: 15.02.2020).). [in Ukrainian].

13. Professional accountants - the future: drivers of change and future skills. The global body for professional accountants (onlajn-vy`dannya). URL:https://cutt.ly/BttZVme (data zvernennya: 15.02.2020).) [in English].

14. V. O. Kudlaj, (2015) Cy`frova gramotnist` osoby`stosti v konteksti rozvy`tku informacijnogo suspil`stva [Digital literacy of the personality in the context of development of information society] Visny`k Mariupol's`kogo derzhavnogo universy tetu. - The bulletin of the Mariupol state university [in Ukrainian].

15. «Cy`frova adzhenda Ukrayiny` - 2020». [Elektronny`j resurs]. Dostupno: https://cutt.ly/NttBrYT [in Ukrainian].

Стаття надійшла до редакції 18.02.2020 р. 